\title{
Acute restraint stress triggers progesterone withdrawal and endometrial breakdown and shedding through corticosterone stimulation in mouse menstrual-like model
}

\author{
Shu-Fang Wang ${ }^{1,2,3}$, Xi-Hua Chen ${ }^{1}$, Bin He ${ }^{1}$, De-Dong Yin ${ }^{1}$, Hai-Jun Gao ${ }^{4}$, Hao-Qi Zhao ${ }^{1,2}$, \\ Nan Nan ${ }^{1,2}$, Shi-Ge Guo ${ }^{1,2}$, Jian-Bing Liu' ${ }^{1,2,5}$, Bin Wu ${ }^{1,2}$ and Xiang-Bo Xu' \\ ${ }^{1}$ Reproductive Physiology Laboratory, National Research Institute for Family Planning, Beijing, China, ${ }^{2}$ Graduate \\ School of Peking Union Medical College, Beijing, China, ${ }^{3}$ Department of Forensic Medicine, Xinxiang Medical \\ University, Xinxiang, Henan, China, ${ }^{4}$ Department of Obstetrics \& Gynecology, Baylor College of Medicine, Houston, \\ Texas, USA and ${ }^{5}$ Department of Cell Biology \& Genetics, Shanxi Medical University, Taiyuan, Shanxi, China
}

Correspondence should be addressed to X-B Xu; Email: xiangboxuhappy@126.com

\begin{abstract}
Stress impacts the reproductive axis at the level of the hypothalamus and the pituitary gland, which exert an effect on the ovary. Menstruation is regulated by the hypothalamic-pituitary-ovary (HPO) axis. However, the role of stress in menstruation remains unclear. The objective of this study was to explore the role of stress in endometrial breakdown and shedding, using the pseudopregnant mouse menstrual-like model. Female mice were mated with vasectomized males and labeled day 0.5, upon observation of a vaginal seminal plug. On day 3.5, decidualization was induced in pseudopregnant mice using arachis oil. On day 5.5, pseudopregnant mice with artificial decidualization were placed in restraint tubes for $3 \mathrm{~h}$. The findings indicated that acute restraint stress resulted in the disintegration of the endometrium. While corticosterone concentration in the serum increased significantly due to restraint stress, follicle-stimulating hormone (FSH), luteinizing hormone (LH) and progesterone (P4) levels in the serum decreased significantly. An endometrial histology examination indicated that progesterone implants may rescue $\mathbf{P 4}$ decline caused by acute stress and block endometrium breakdown and shedding. In addition, mice were treated with metyrapone, an inhibitor of corticosterone synthesis, $1 \mathrm{~h}$ prior to being subjected to restraint stress. Interestingly, metyrapone not only inhibited stress-induced endometrium breakdown and shedding, but also prevented stress-induced reduction of P4, LH and FSH. Furthermore, real-time PCR and western blot showed that mRNA and protein expression of CYP11A1 (cytochrome P450, family 11, subfamily A, polypeptide 1) and steroidogenic acute regulatory protein (StAR), the two rate-limiting enzymes for progesterone synthesis in the ovary, decreased following acute stress. But metyrapone prevented the reduction of StAR expression induced by restraint stress. Overall, this study revealed that acute stress results in an increase in corticosterone, which may inhibit LH and FSH release in the serum and CYP11A1 and StAR expression in the ovary, which finally leads to the breakdown and shedding of the endometrium. These experimental findings, based on the mouse model, may enable further understanding of the effects of stress on menstruation regulation and determine the potential factors affecting stress-associated menstrual disorders.

Reproduction (2019) 157 149-161
\end{abstract}

\section{Introduction}

Menstruation is regulated by the hypothalamicpituitary-ovary (HPO) axis. Progesterone withdrawal, regulated by the ovary, is the initial factor which triggers endometrial breakdown and bleeding in menstruation. However, upstream endocrine regulation of this process is unclear, and whether stress indirectly regulates menstruation through progesterone maintenance has not been determined.

Stress has long been reported to interrupt normal reproductive behavior, such as ovarian quiescence, amenorrhea, infertility, preterm delivery, miscarriage, intrauterine growth restriction, endometrial receptivity and stillbirth in women (Xiao et al. 1999, Liu et al. 2015). However, menstrual disorder, which is characterized by abnormal cycle intervals and menorrhagia, is a common disease in females (Kjerulff et al. 1996, Herzog \& Friedman 2001). Some survey data indicate that stress may be a major contributor to menstrual disorders, and an association has been documented between stress and various menstrual irregularities (Warren \& Fried 2001, Rafique \& Al-Sheikh 2018). Several environmental stressors are also thought to be associated with hypothalamic amenorrhea (Allaway et al. 2016). A previous study where 393 female students were enrolled found that stress led to pre-menstrual syndrome, oligomenorrhea, amenorrhea, 
and menorrhagia. Menorrhagia, but not amenorrhea, was the most common and prevalent menstrual disorder (Ekpenyong et al. 2011). O'Neill (1958) divided common stress disorders into eight groups, one of which included menorrhagia, indicating that menorrhagia is one of the bodily responses to stress.

The hypothalamic-pituitary-adrenal (HPA) axis plays an important role in stress response (Fenchel et al. 2015). Corticotropin-releasing hormone $(\mathrm{CRH})$, produced by parvicellular neurons of the hypothalamus, stimulates adrenocorticotropic hormone (ACTH) secretion from the pituitary. ACTH acts on the cortex of adrenal glands and stimulates the synthesis and release of glucocorticoids (de Kloet et al. 2005, Chen et al. 2016). Glucocorticoids suppress $\mathrm{GnRH}$ secretion, $\mathrm{LH}$ release, estradiol and progesterone synthesis in the gonads. Additionally, women with functional hypothalamic amenorrhea had higher measured 24-h serum cortisol concentrations compared to controls (Gordon et al. 2017). Other studies reported exogenous corticosteroids can negatively regulate the HPO axis and result in heavy and painful menstrual bleeding (Gitkind et al. 2010). These studies indicate that stress-induced cortisol may play a role in menstruation. However, direct evidence is lacking and the mechanism by which stress affects menstruation is unclear and requires further study.

Studies on the menstruation mechanism are limited in humans owing to limited experimental resources and in vivo intervention. Fortunately, mouse menstruationlike models have been developed to overcome this limitation. The mouse menstruation-like model, which mimics physiologic withdrawal of progesterone, was generated in 1984 (Finn \& Pope 1984). In this model, progesterone withdrawal leads to endometrial breakdown by inducing stromal cell decidualization. Further refinements were made, and the model was optimized by Brasted (Brasted et al. 2003). Moreover, we have developed a mouse menstrual-like model based on pharmacological withdrawal of progesterone (Xu et al. 2007). Further, pseudopregnant mice were used to build the pseudopregnant mouse menstruallike model (Cao et al. 2010, Rudolph et al. 2012), in this study, we describe the method used to establish this model. Vasectomized male mice were mated with estrous female mice to obtain pseudopregant female mice. Subsequently, decidualization was induced by arachis oil on day 3.5 in pseudopregnant mice. The 49-h duration of induction was optimized both in a study by Brasted (Brasted et al. 2003) and in our studies (Xu et al. 2007, Li et al. 2012, Wang et al. 2013, Chen et al. 2015). On day 5.5, the mice were placed in restraint tubes. After restraint stress treatment, the mice were removed from the tubes (designated as $0 \mathrm{~h}$ ). In a previous study, as well as our studies, the focal death of the endometrium occurred $8 \mathrm{~h}$ after progesterone withdrawal in a mouse menstrual-like model. The zone of death was further expanded at $16 \mathrm{~h}$, which is a critical period for progesterone (P4) withdrawal. At $24 \mathrm{~h}$, decidual stromal cells showed complete death and the entire decidual zone shed from the basal zone. Time points in this study were chosen based on previous studies. In this model bilateral ovaries suitable for endocrine analysis were carefully preserved, providing an important opportunity to study complicated endocrine regulation during menstruation. Thus, the effects of stress on menstruation were studied using the pseudopregnant mouse menstrual-like model.

This report provides direct evidence that stress leads to progesterone withdrawal, which triggers endometrial breakdown and bleeding in pseudopregnant mice with artificial decidualization.

\section{Materials and methods}

\section{Animals and experimental design}

Female virgin ICR mice (8-10 weeks old) were obtained from the Animal Services of the National Research Institute. Mice were bred under controlled light (lights on from 08:00 to $20: 00 \mathrm{~h})$ and temperature $\left(21 \pm 1^{\circ} \mathrm{C}\right)$ conditions and were allowed free access to food and water. All experimental and surgical procedures were approved by the Animal Ethics Committee of the National Research Institute for Family Planning.

Female mice were placed with vasectomized males and were considered day pseudopregnant, and labeled day 0.5, upon observation of a vaginal seminal plug. On day 3.5 at $15: 30 \mathrm{~h}, 20 \mu \mathrm{L}$ of arachis oil were injected into the bilateral uterine lumen of each mouse through a dorsal incision to induce decidualization. These mice were subsequently divided into six groups that were control group, restraint stress group, metyrapone group, vehicle control group, sham operation group and P4 implant group (Fig. 1). On day 5.5 at $16: 30 \mathrm{~h}$, restraint stress group mice were individually put into transparent plastic $50 \mathrm{~mL}$ centrifuge tubes with ventilation holes which allowed the mice to breathe freely, according to previous descriptions (Liu et al. 2015, Tung et al. 2016). After 3-h restraint stress, the mice were removed from the tubes (designated as $0 \mathrm{~h}$ ) and returned to their cages. During the restraint period, mice had no access to water and food. Meanwhile, control group mice remained in their cages and were denied water and food for $3 \mathrm{~h}$. The difference between the control group and stress group was that the mice in the stress group were placed in $50 \mathrm{~mL}$ centrifuge tubes during the restraint stress, but the mice in the control group were in cages. Control group and restraint stress group mice were killed by cervical dislocation before stress or at $0,1,4,8,16$ and $24 \mathrm{~h}$ ( $n=7-9$ for each time point), and their uterine horns and ovaries were harvested. On day 5.5 at 15:30h, progesterone (P4) implants containing $50 \mathrm{ng}$ of $\mathrm{P} 4$ were inserted subcutaneously into the back of the mice (Sigma-Aldrich Inc.) in the P4 implant group. Subsequently, at 16:30h, mice were put into restraint tubes for $3 \mathrm{~h}$, after which mice subjected to restraint stress were removed from the tubes (designated as $0 \mathrm{~h}$ ). P4 implant group mice were killed by cervical dislocation before stress or at 0,16 and $24 \mathrm{~h}$ ( $n=7-9$ for each time point) after restraint stress, and their uterine horns were harvested. The P4 


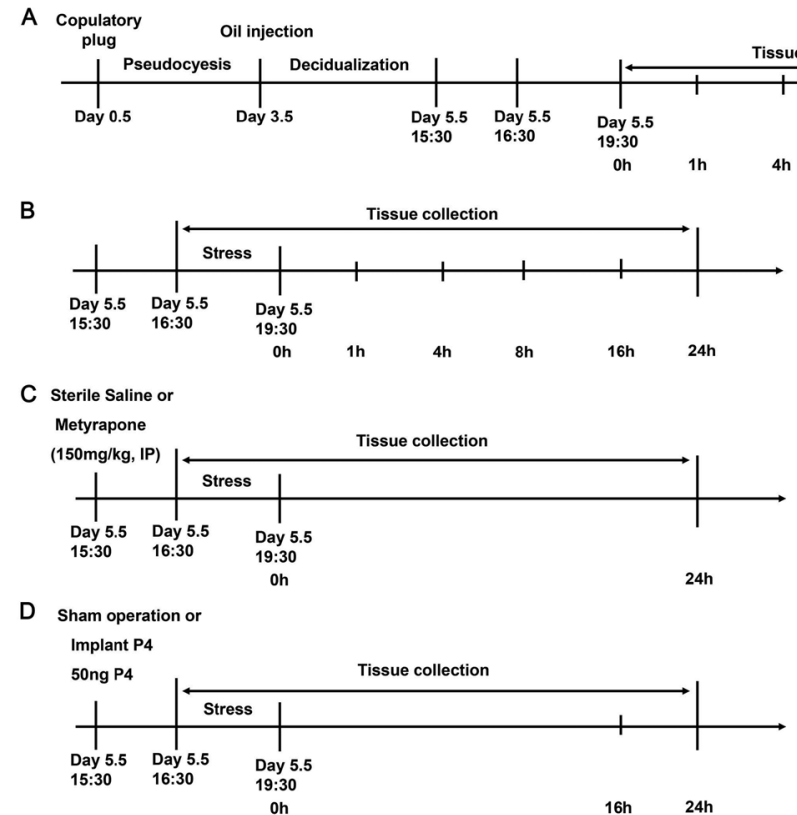

implants were prepared as previously described (Brasted et al. 2003). Sham-operated mice, which underwent all the same procedures except P4 implantation, were killed before stress or at 0,16 and $24 \mathrm{~h}$ after restraint stress $(n=7-9$ for each time point), and their uterine horns were harvested. Metyrapone group (150 mg/kg metyrapone; intraperitoneal injection, IP; at 15:30 h on day 5.5) and vehicle control group (saline, IP; at $15: 30 \mathrm{~h}$ on day 5.5 ) were killed by cervical dislocation before stress or at 0 and $24 \mathrm{~h}$ after restraint stress $(n=7-9$ for each time point), and their uterine horns and ovaries were harvested. In these six groups, part of each horn and one ovary were fixed in $4 \%$ paraformaldehyde solution, the remaining part of the uterus and the other ovary were snap frozen in liquid nitrogen and stored at $-80^{\circ} \mathrm{C}$ for further analysis. Blood samples were simultaneously collected from the orbital sinus of the killed mice and stored at room temperature for $1 \mathrm{~h}$, centrifuged for $10 \mathrm{~min}$ at $3000 \mathrm{~g}$ at room temperature, supernatant was extracted and the resulting serum was stored at $-80^{\circ} \mathrm{C}$ until measurements of P4, estrogen (E2), corticosterone, FSH and $\mathrm{LH}$ concentration were performed.

\section{Immunohistochemistry}

Harvested endometrial tissues were embedded in paraffin and cut into $5 \mu \mathrm{m}$ sections using a microtome (Leica, RM2235). Briefly, the cross-sections were dewaxed in xylene and rehydrated in ethanol, and then treated by an antigen retrieval procedure (citrate buffer, $\mathrm{pH} 6.0 ; 98^{\circ} \mathrm{C}$ heat for $20 \mathrm{~min}$ ). Sections were incubated in $3 \% \mathrm{H}_{2} \mathrm{O}_{2}$ at room temperature for $10 \mathrm{~min}$ in order to quench the endogenous hydrogen peroxidase activity. Nonspecific staining was blocked with 5\% goat serum for $30 \mathrm{~min}$ at room temperature. Sections were then incubated with rabbit anti-MMP-13 antibody (1:3000, ab39012, Abcam), rabbit anti-MMP-9 antibody (1:300, ab38898, Abcam), rabbit anti-glucocorticoid receptor antibody (1:300, ab3578, Abcam) and rabbit anti-MMP-2 antibody (1:1500, YT2798,
Figure 1 Schematic representation of the experimental design and timeline for restraint stress. Female mice were mated with vasectomized male mice. Pseudopregnancy in female mice was confirmed by observing vaginal plug (0.5 day). On day 3.5 at 15:30, $20 \mu \mathrm{L}$ of arachis oil was injected into the bilateral uterine lumen of each mouse to induce decidualization. (A) Control group: on day 5.5, 19:30 was designated as $0 \mathrm{~h}$. (B) Restraint stress group: on day 5.5, 19:30 was designated as $0 \mathrm{~h}$. On day 5.5 from 16:30 to 19:30, pseudopregnant mice were individually put into transparent $50 \mathrm{~mL}$ plastic centrifuge tubes for $3 \mathrm{~h}$. The end of the stress period at 19:30 was recorded as $0 \mathrm{~h}$. (C) Metyrapone group and vehicle group (sterile saline): on day 5.5 at 19:30 was designated as 0 h. (D) P4 implant group: on day 5.5 at 15:30, P4 implants were inserted, and from 16:30 to 19:30, pseudopregnant mice were stressed for $3 \mathrm{~h}$. Sham-operated mice underwent the same procedures except for the implantation of P4.
ImmunoWay Biotechnology Company) at $4{ }^{\circ} \mathrm{C}$ overnight. Meanwhile, matched rabbit non-immune immunoglobulin G (IgG) was used as a negative control. Subsequently, the sections were treated with horseradish peroxidase (HRP)conjugated secondary antibodies (PV-6001; Zhongshan, Beijing, China) for $30 \mathrm{~min}$ at $37^{\circ} \mathrm{C}$. The immunoactive protein was visualized with 3,3'-diaminobenzidine tetrahydrochloride $(\mathrm{DAB})$ and nuclei were counterstained with hematoxylin. Each treatment step was followed by three 5-min washes in PBS. The sections were dehydrated via an alcohol gradient, cleared in xylene and mounted with neutral gum. Positive signal in endometrium was analyzed using Image Pro Plus V6.0 (Media Cybernetics, Rockville, MD, USA). Mean optical density of the images was designated as representative MMP-2,-9,-13 staining intensity.

\section{Real-time polymerase chain reaction (RT-PCR)}

Total RNA extraction and RT-PCR experiments were carried out according to the manufacturer's instructions. In brief, total RNA was extracted from the mouse ovary using TRIzol Reagent (Invitrogen, Carlsbad, CA, USA). cDNA was synthesized with $2 \mu \mathrm{g}$ total RNA using Moloney murine leukemia virus (M-MLV) reverse transcriptase (Takara Bio, Otsu, Japan). Reverse transcription was performed with oligo (dT) primers $(25 \mathrm{pmol}$, Takara Bio) and random primers (50 pmol, Takara Bio) according to the manufacturer's protocols. Gene expression was analyzed using an ABI Prism 7700 Sequence Detector System (PE Applied Biosystems), SYBR Premix Ex Taq II (Takara Bio) and sequence-specific primers for each gene. The cycling parameters were as follows: an initial activation cycle at $95^{\circ} \mathrm{C}$ for $5 \mathrm{~min}$, followed by 40 cycles of denaturation $\left(95^{\circ} \mathrm{C}\right.$ for $10 \mathrm{~s})$, annealing and amplification $\left(60^{\circ} \mathrm{C}\right.$ for $\left.34 \mathrm{~s}\right)$. Actb was used as the internal control, and all data were normalized to Actb expression. Relative quantification was calculated using the $2^{-\Delta \Delta \mathrm{Ct}}$ method, in which $\Delta \Delta \mathrm{Ct}$ is the difference of 
the calibrated $\mathrm{Ct}$ value between the two groups. The primer sequences were as follows:

- Star forward, 5' - TGCATGGTGCTTCATCCACT -3';

- Star reverse, 5' - GCCACCCCTTCAGGTCAATA -3';

- Cyp11a1 forward, 5'- TCCTTTGAGTCCATCAGCAGT-3';

- Cyp11a1 reverse, 5'-TGGTCCTTCCAGGTCTTAGTTC-3';

- Actb forward, 5' - CATCCGTAAAGACCTCTATGCCAAC-3';

- Actb reverse, 5' - ATGGAGCCACCGATCCACA-3'.

\section{E2, P4, corticosterone, $L H$ and FSH assays}

P4 (Progesterone Radioimmunoassay Kit, BNIBT, Beijing, China) and E2 (Estradiol Radioimmunoassay Kit, BNIBT) serum levels were measured using radioimmunoassay, according to the manufacturer's instructions. Corticosterone (Corticosterone ELISA Kit, ab108821, London, UK), FSH (FSH ELISA Kit, F111SC; HCB, Canada) and LH (LH ELISA Kit, L059SC; HCB) were determined by ELISA assay. The intra-assay coefficients of variation for $\mathrm{P} 4, \mathrm{E} 2$, corticosterone, $\mathrm{FSH}$ and $\mathrm{LH}$ were less than $7,9,6,10$ and $9 \%$, respectively. The inter-assay coefficients of variation for $\mathrm{P} 4, \mathrm{E} 2$, corticosterone, $\mathrm{FSH}$ and $\mathrm{LH}$ were less than $12,15,13,14$ and $12 \%$, respectively.

\section{Western blotting}

Immunoblotting was performed as described previously (Wu et al. 2014). RIPA lysis buffer was used to extract total protein from mice ovaries. In total, $40 \mu \mathrm{g}$ of protein were separated in 10\% Bis-Tris gels and then transferred onto PVDF membranes. The membranes were blocked for $1 \mathrm{~h}$ at room temperature (RT) with TBST $(50 \mathrm{mM}$ Tris- $\mathrm{HCl}, 150 \mathrm{mM} \mathrm{NaCl}$ and $0.1 \%(\mathrm{v} / \mathrm{v})$ Tween-20) containing 5\% (w/v) nonfat dried milk and then incubated with rabbit antimouse CYP11A1 (1:600, Proteintech Group, Chicago, IL, USA), rabbit antimouse StAR (1:300, Proteintech Group), rabbit anti-glucocorticoid receptor (1:1000, ab3578, Abcam) and mouse antimouse $\beta$-actin (1:2000, Zhongshan, Beijing, China ) antibodies overnight at $4{ }^{\circ} \mathrm{C}$. Membranes were then washed with TBST and incubated with HRP-labeled secondary antibody $(1: 10,000)$ for $1 \mathrm{~h}$ at room temperature. Protein bands on the membrane were visualized by an enhanced chemiluminescence system (Applygen Technologies Inc., Beijing, China) on X-ray film.

\section{Statistical analysis}

The values were expressed as means \pm S.D. Statistical significance of the quantitative data were evaluated by twoway ANOVA using SPSS19 software (SPSS Sciences) followed by Tukey's HSD test. A $P$ value of $<0.05$ was considered statistically significant and is indicated by an asterisk in figures.

\section{Results}

\section{Restraint stress resulted in the disintegration of the endometrium}

At $24 \mathrm{~h}$ following restraint stress, bleeding was observed in the vaginal orifice of mouse, while no bleeding was observed in the control group, indicating that restraint stress may lead to the disintegration of mouse endometrium by vaginal bleeding. Further, macroscopic analysis showed that the uterine horns were dark red in the restraint stress group and light pink in the control group (Fig. 2A and D). The majority of decidualized stromal cells exhibited necrosis and the functional layer was separated from the basal layer and sloughed into the uterine lumen in the restraint stress group (Fig. 2E and F). However, the above-mentioned changes in endometrium did not occur in the control group (Fig. 2B and C).

\section{Effects of restraint stress on the expression of MMPs}

Because disintegration of endometrium was observed at $24 \mathrm{~h}$ following restraint stress, we investigated changes which occurred in the endometrium at times prior to $24 \mathrm{~h}$. At $16 \mathrm{~h}$, decidual stromal cell death and hemorrhage occurred in the sub-epithelium focal zone in the restraint stress group, whose decidual stromal cells showed nuclear pyknosis or karyorrhexis, cytoplasmic degeneration and a universal lack of discernible cytoplasmic borders. However, the whole endometrium was structurally intact in the control group (Fig. 3A).

Matrix metalloproteinases (MMPs) played an important role in the degradation of the extracellular matrix and the final endometrial breakdown. Therefore, MMPs may
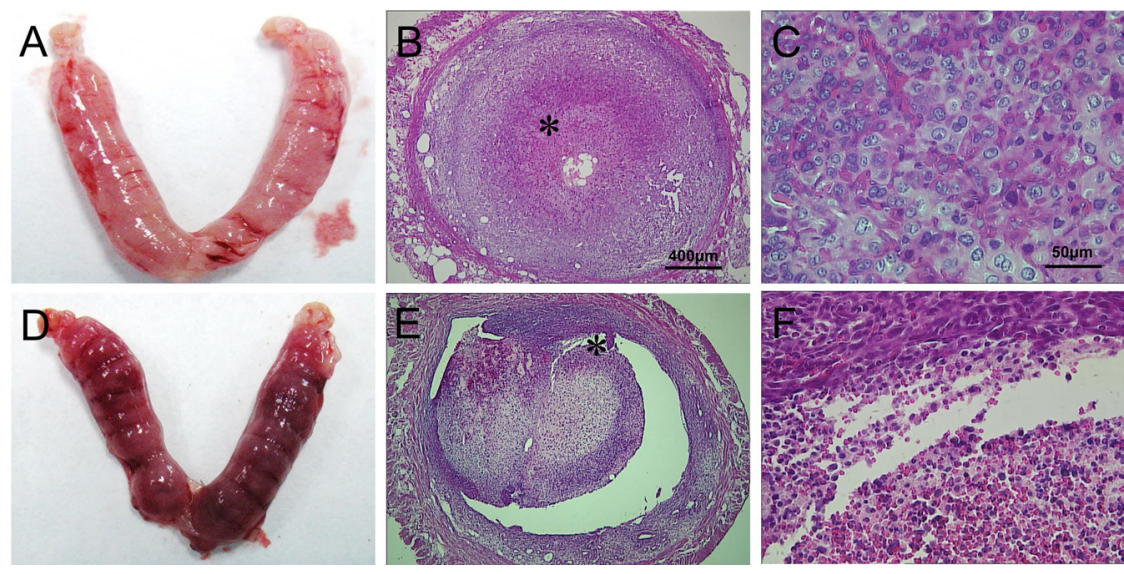

Figure 2 Macroscopic and histological examination of mouse uterus tissues $24 \mathrm{~h}$ after restraint stress. (A), (B) and (C) represent control group. (D), (E) and (F) represent restraint stress group. (A) and (D) represent the macroscopic observation. The uterine horns in control group are light pink in color, whereas those in restraint stress group were dark red. (B), (C), (E) and (F) represent morphological changes in the two groups. The whole endometrium was structurally intact in the control group, whereas the functional layer was sloughed off into the uterine lumen in the restraint stress group. (C) and (F) represent higher magnification of the areas indicated by an asterisk in (B) and (E). 
A
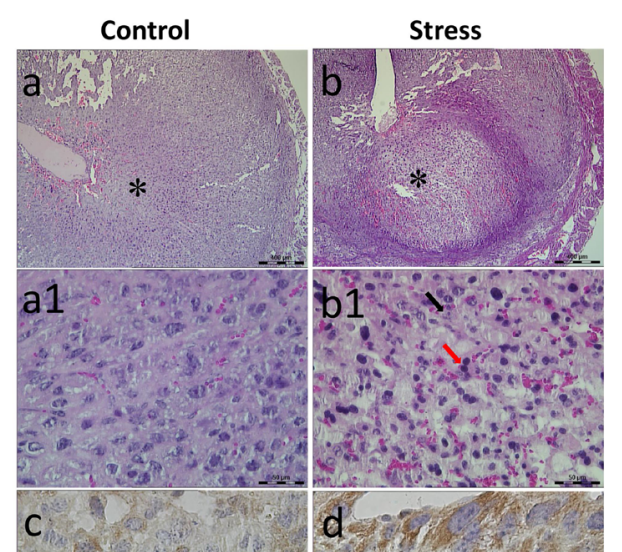

MMP2
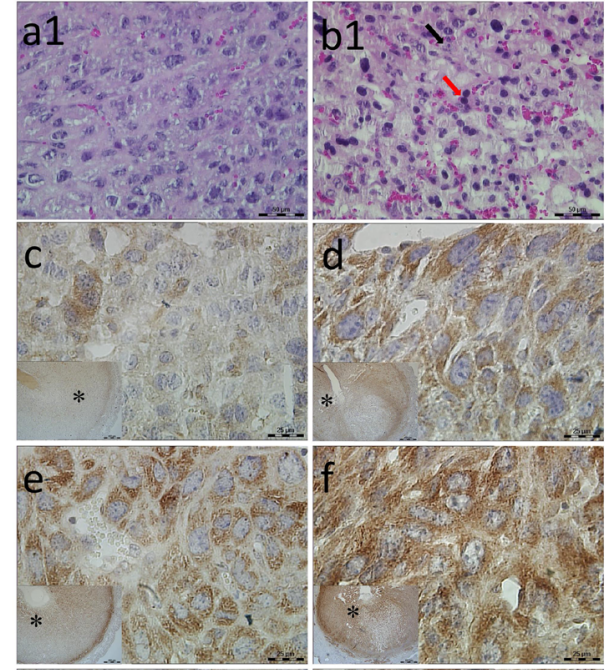

MMP9

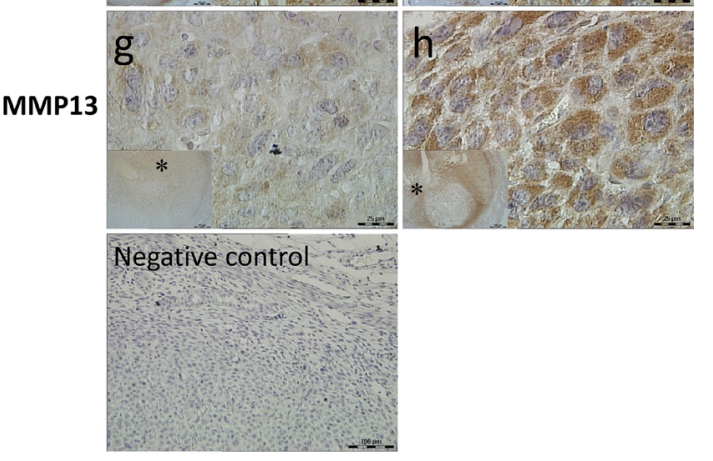

B

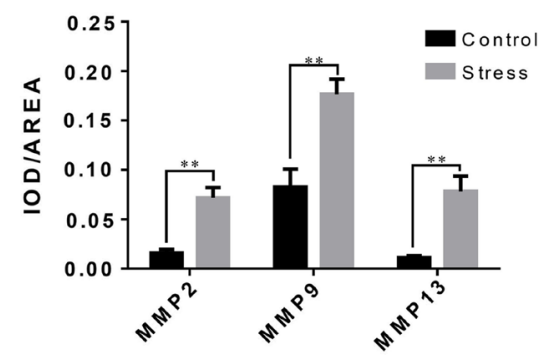

Figure 3 Immunocytochemistry for MMP-2, MMP-9 and MMP-13 expression patterns $16 \mathrm{~h}$ after restraint stress. (A): (a) and (b) represent morphological changes in the control and stress groups, respectively, $16 \mathrm{~h}$ after restraint stress. (a1) and (b1) are higher magnification of the areas indicated by an asterisk in (a) and (b). Pyknosis and karyorrhexis are indicated in (b1) by a red arrow and black arrow, respectively. (c and d) MMP-2 (e and f) MMP-9 and ( $g$ and h) MMP-13 staining was observed by immunohistochemistry. MMP-2-, MMP-9- and MMP-13-positive signals were stronger in decidual stromal cells in the stress group than that in the control group. Insert images are parts of cross-section fields of uterine tissues. (B) Quantification and comparison of MMP-2, -9, -13 expression in endometrium after restraint stress. ${ }^{* *} P<0.01$. act as molecular markers of endometrial breakdown and shedding. Our previous studies have shown that endometrial breakdown was strongly related to MMPs such as MMP-2, MMP-9, MMP-10 and MMP-13 (Li et al. 2012, Wang et al. 2013). In this study, we examined the effects of restraint stress on the expression of MMP-2, MMP-9 and MMP-13. Immunohistochemically, MMP-2positive signal was stronger in decidual stromal cells of the stress group than that in those of the control group (Fig. 3A). In decidual stromal cells, MMP-9- and MMP13-positive signals were also significantly stronger in the stress group than those in the control group (Fig. 3A). Quantification analysis revealed that MMP-2, MMP-9 and MMP-13 were significantly increased in the restraint stress group compared to the control group (Fig. 3B). Considered together, these results demonstrated that restraint stress may increase the expression of MMP-2, MMP-9 and MMP-13, and further indicated that MMP2, MMP-9 and MMP-13 may also be associated with tissue breakdown caused by restraint stress.

\section{Changes in serum concentrations of corticosterone, $F S H$ and $L H$ after restraint stress}

Central effects of the stress response were mainly in the HPA axis. Corticosterone was the major mediator of stress response. In order to determine whether restraint stress causes changes in corticosterone, its concentration in serum was examined. At $0 \mathrm{~h}$ following restraint stress, the serum corticosterone level of restraint stress mice was higher than that of control mice and the pre-stress group, which were killed by cervical dislocation before restraint stress, at $16: 30$ on day $5.5(P<0.01)$, and then decreased rapidly at $16 \mathrm{~h}$ compared to $0 \mathrm{~h}(P<0.01)$, and at $16 \mathrm{~h}$, there were no obvious differences compared to the control group and the pre-stress group (Fig. 4A). We further traced serum levels of FSH and LH discharged from the pituitary. Following restraint stress, the serum concentration of FSH decreased rapidly at $0 \mathrm{~h}$ compared to the control group and the pre-stress group $(P<0.01)$. At 1 and $4 \mathrm{~h}$, there were significant differences in serum FSH levels between the restraint stress group and the control group $(P<0.05)$. However, there was no difference between the two groups at $8 \mathrm{~h}(P>0.05 ;$ Fig. $4 \mathrm{~B})$. Moreover, the results indicated that the $\mathrm{LH}$ content decreased at 0 and $1 \mathrm{~h}$ after restraint stress and that there were significant differences compared to the control group and the pre-stress group $(P<0.01)$. Then, the $\mathrm{LH}$ content in serum increased rapidly. At $4 \mathrm{~h}$, there was no significant difference between the two groups (Fig. 4C).

\section{The expression of $G R$ in endometrium after restraint stress}

Corticosterone functions by binding to its intracellular receptor, the glucocorticoid receptor (GR), which is a transcription factor belonging to the nuclear receptor 
A

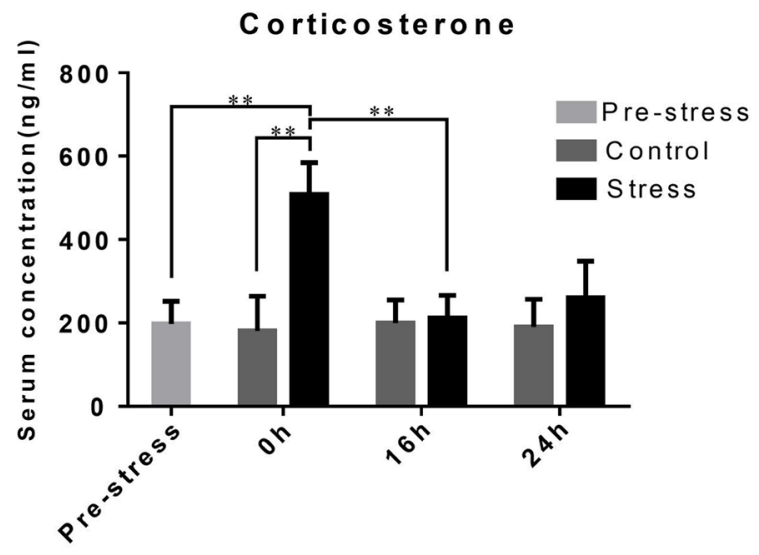

B

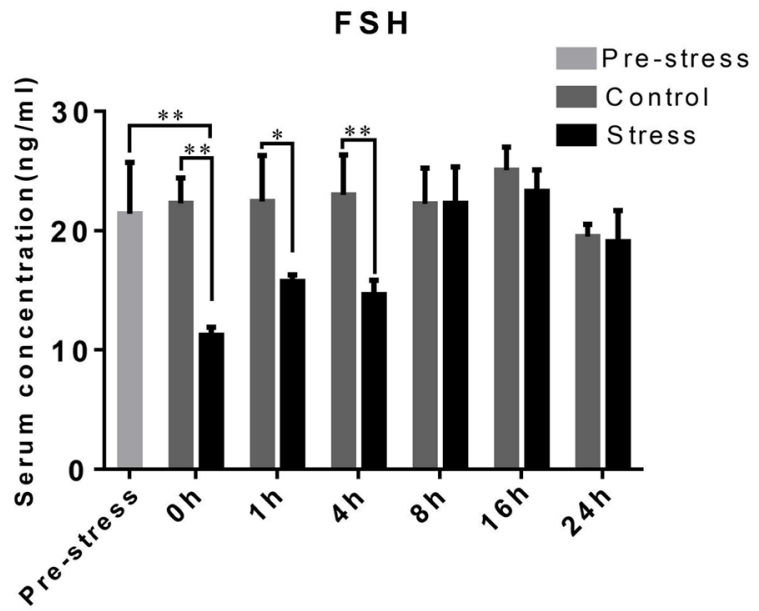

C

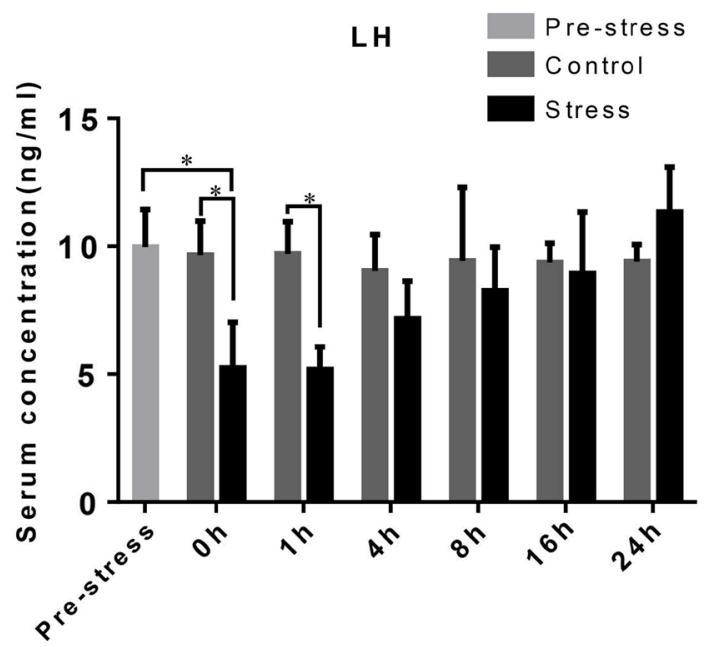

Figure 4 Effect of stress on the concentrations of corticosterone $(\mathrm{ng} / \mathrm{mL}), \mathrm{FSH}(\mathrm{ng} / \mathrm{mL})$ and $\mathrm{LH}(\mathrm{ng} / \mathrm{mL})$. (A), (B) and $(\mathrm{C})$ represent the serum levels of corticosterone, FSH and $\mathrm{LH}$, respectively. Data are represented as mean \pm S.D. of hormone concentration at the different time points. ${ }^{*} P<0.05,{ }^{*} * P<0.01$.

superfamily. In the absence of a ligand, GR resides predominantly in the cytoplasm. When a ligand binds, GR travels to the nucleus from the cytoplasm. The serum concentration of corticosterone increases rapidly at $0 \mathrm{~h}$ after restraint stress (Fig. 4A). Thus, the expression of $\mathrm{GR}$ in the endometrium was explored. At $0 \mathrm{~h}$ following restraint stress, most GR-immunopositive signals were present in the cytoplasm of stromal cells, and there was no difference compared with $16,24 \mathrm{~h}$ and pre stress (Fig. 5A). Moreover, western blot results showed that at 0,16 and $24 \mathrm{~h}$, the expression of GR in the stress group was not significantly different compared to control or pre-stress groups (Fig. 5B).

\section{Serum levels of E2 and P4 after the restraint stress}

The state of the endometrium is regulated by estrogen and progesterone, and P4 withdrawal triggers endometrial breakdown and shedding. Therefore, we measured serum concentrations of E2 and P4. At 0, 16 and $24 \mathrm{~h}$ after restraint stress, serum E2 level of the restraint stress group was not significantly different from that of either the pre-stress group or the control group $(P>0.05)$ (Fig. 6A). Serum P4 levels in restraint stress group decreased at $0 \mathrm{~h}$ and was significantly different compared to those of the control group and the pre-stress group $(P<0.01)$. Then, serum levels of $\mathrm{P} 4$ in the restraint stress group continued to decline rapidly and reached a very low level at $24 \mathrm{~h}$ compared to $0 \mathrm{~h}(P<0.05)$. Moreover, $\mathrm{P} 4$ levels in the restraint stress group were obviously reduced from 0 to $24 \mathrm{~h}$ compared to those of the control group and the pre-stress group $(P<0.01)$. However, P4 concentration was not changed from 0 to $24 \mathrm{~h}$ in the control group $(P>0.05$; Fig. 6B). These results showed that restraint stress may trigger progesterone withdrawal.

\section{Effect of metyrapone on endometrial breakdown and shedding during the stress period}

Metyrapone, an inhibitor of cytochrome P450, inhibits corticosterone synthesis. Metyrapone inhibited endometrial breakdown and shedding caused by restraint stress. At $24 \mathrm{~h}$ following restraint stress, endometrial breakdown was observed in the vehicle group, but not in the metyrapone group (Fig. 7A). There was no difference in serum corticosterone concentration between the vehicle group and the metyrapone group prior to stress. At $\mathrm{O} \mathrm{h}$ following restraint stress, the serum concentration of corticosterone in the vehicle group was higher than that in the metyrapone group $(P<0.01$; Fig. $7 \mathrm{~B})$. This implied that metyrapone may effectively inhibit the synthesis of corticosterone during restraint stress. Moreover, serum P4 levels were not different between the vehicle group and the metyrapone group prior to stress. But at 0 and $24 \mathrm{~h}$ after restraint stress, serum P4 concentrations were obviously lower in the metyrapone group than in the vehicle group $(P<0.01 ;$ Fig. $7 \mathrm{C})$. At $0 \mathrm{~h}$, the serum level of FSH in the metyrapone group was significantly higher than that in the vehicle group. There was no obvious difference in the serum levels of $\mathrm{FSH}$ before and after stress in the vehicle group (Fig. 7D). 
A
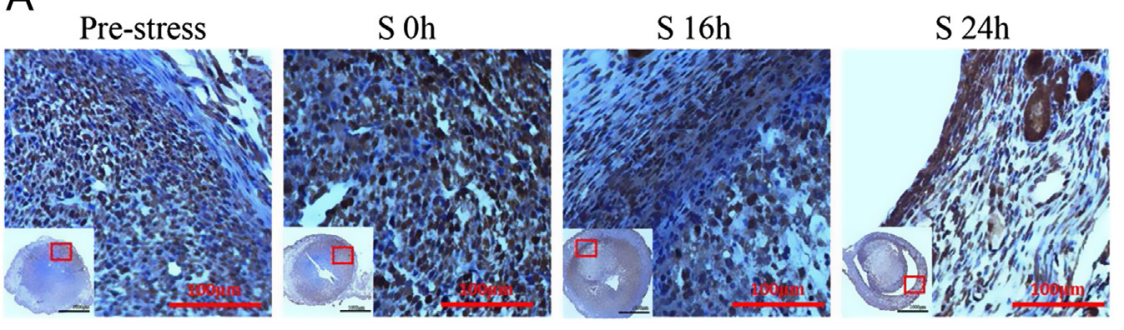

B

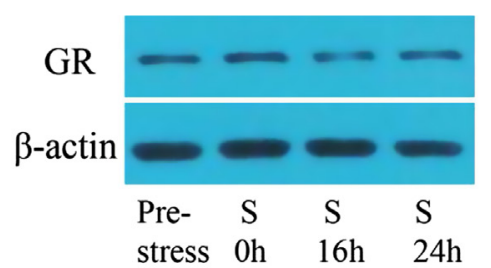

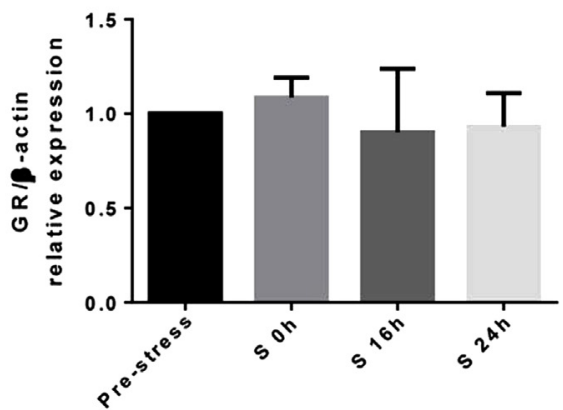

Figure 5 Expression of glucocorticoid receptor $(\mathrm{GR})$ in endometrium after restraint stress. (A) Immunohistochemical staining: There was no significant difference in the intensity of staining of GR between the pre-stress and stress $(0,16,24 \mathrm{~h})$ groups. Insert images are parts of cross-section fields of uterine tissues; magnified fields are indicated by the red square. (B) Western blot analysis: No significant expression of GR was observed in the endometrium of mice before stress as compared to expressions at $0,16,24 \mathrm{~h}$ after stress. S, stress group. Data are represented as mean \pm S.D. $\beta$-actin was used as a loading control.
At $0 \mathrm{~h}$, there was no significant difference between the serum LH levels of the metyrapone group and the prestress group. However, at $\mathrm{Oh}$, serum $\mathrm{LH}$ concentrations obviously decreased in the vehicle group compared to that in the pre-stress group. Moreover, there was no difference between the metyrapone group, the vehicle group and the pre-stress group. At $0 \mathrm{~h}$, serum $\mathrm{LH}$ level in the metyrapone group was obviously higher than that in the vehicle group (Fig. 7E). The result showed that metyrapone, which inhibits corticosterone synthesis, may prevent a decrease in progesterone during restraint stress by inhibiting a decrease in $\mathrm{LH}$, leading to the inhibition of endometrial disintegration.

\section{Progesterone implants can reverse the breakdown and shedding of the endometrium caused by restraint stress}

Above results indicated that progesterone decline induced by restraint stress may be a major factor that causes the breakdown and shedding of the endometrium in mice. In order to validate the above indication, progesterone was implanted $1 \mathrm{~h}$ before restraint stress. In order to compare serum progesterone concentration with the pre-stress group and to prove the efficacy of the sustained-release progesterone tubes used by us as also to observe the condition of the uterus at $24 \mathrm{~h}$ after restraint stress, the mice were killed prior to restraint stress, and 0,16 and $24 \mathrm{~h}$ after restraint stress. Results showed that the endometrium in mice without progesterone implantation broke down at $24 \mathrm{~h}$ after restraint stress (Fig. $8 \mathrm{~B}$ and b). However, in the progesterone implantation group, the endometrium did not break down following restraint stress (Fig. 8A and a). To evaluate progesterone release from implantation, levels of progesterone in mice serum were tested. P4 serum level in pre-stress P4 implant group was higher than that of the pre-stress sham operation group $(P<0.01$; Fig. $8 \mathrm{C})$. From 0 to $24 \mathrm{~h}$ following restraint stress, serum concentrations of progesterone in the $\mathrm{P} 4$ implant group were significantly higher than those of the stress group and the sham operation group $(P<0.01$; Fig. $8 \mathrm{C})$. At the same time point, there was no difference between the sham operation group and the P4 implant group. In order to confirm the efficacy of restraint stress, we further examined serum corticosterone, a major stress effect factor, which increased after restraint stress at $\mathrm{Oh}$ in the sham operation group, stress group and $\mathrm{P} 4$ implant group, to levels that were significantly different compared to the pre-stress group (Fig. 8D). This showed that restraint stress was effective in the sham operation group, the P4 implant group and the stress group. However, there was no significant difference between these three groups (Fig. 8D). This also indicated that the operation had no obvious effect on the results of the experiment. These findings showed that progesterone implants may reverse endometrial breakdown and shedding caused by restraint stress.

\section{Restraint stress suppressed CYP11A1 and StAR expression in the ovary}

As progesterone in the serum decreases following restraint stress, we studied rate-limiting enzymes related to progesterone synthesis at mRNA and protein level. We first analyzed Cyp11a1 expression patterns up to $24 \mathrm{~h}$ after restraint stress. Cyp11a1 mRNA expression in the stress group decreased significantly at $0 \mathrm{~h}$ compared to that in the control group $(P<0.01)$, but then began to increase gradually until there was no significant difference compared to the control group at 16 h (Fig. 9A). CYP11A1 protein significantly decreased from 8 to $16 \mathrm{~h}$ compared to the control group $(P<0.05$; 

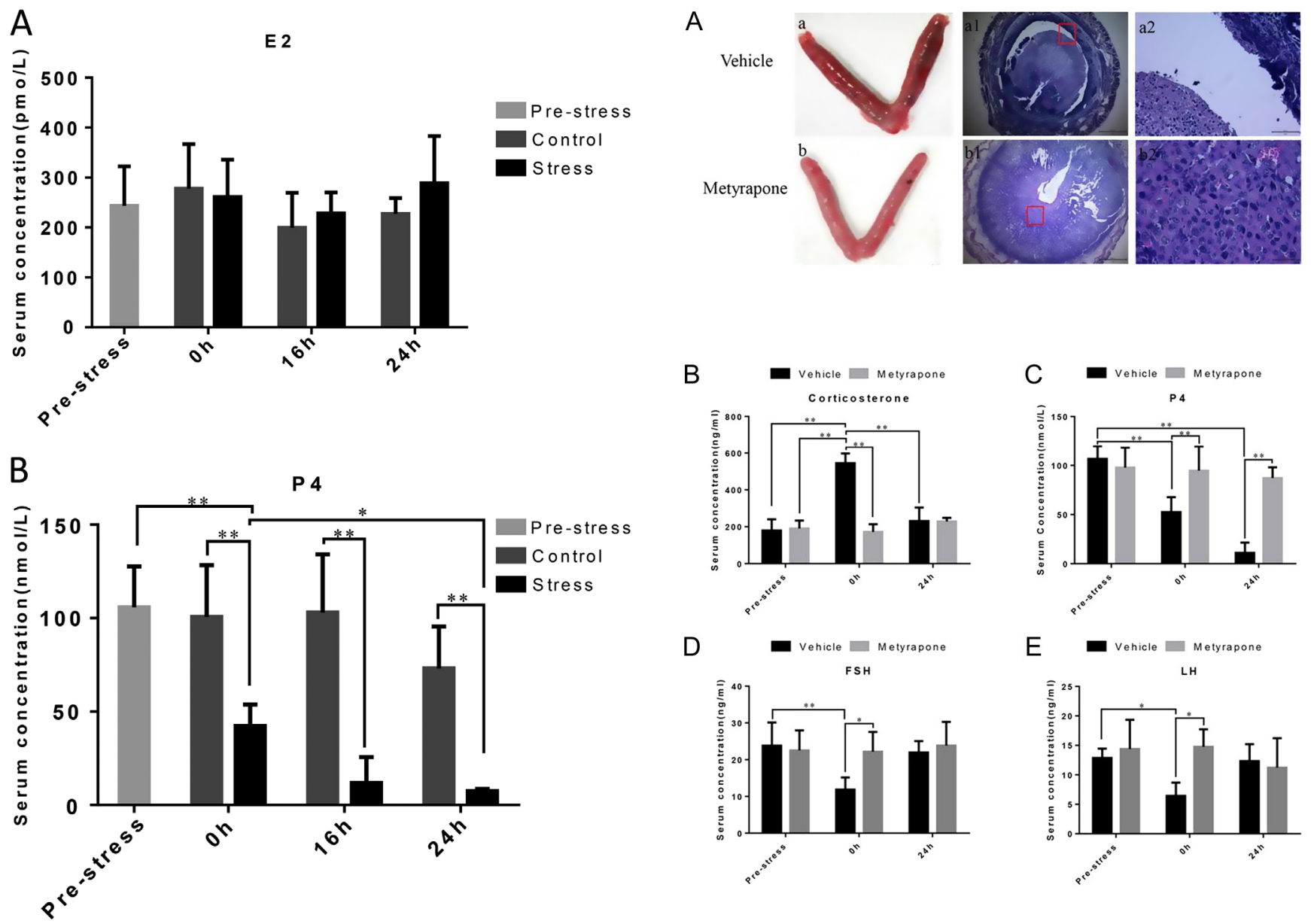

Figure 6 Effect of stress on the serum levels of E2 (pmol/L) and progesterone $(\mathrm{nmol} / \mathrm{L})$ in serum. Data were represented as mean \pm S.D. of hormone concentration at the different time points. (A) E2 concentrations between the pre-stress and stress groups at different time points were not significant $(P>0.05)$. (B) The serum P4 levels in stress group were significantly lower than those in pre-stress group and control group at the same point of time. ${ }^{* *} P<0.01$.

Fig. 9B and C). Moreover, Star mRNA expression in the stress group showed a significant decrease from 0 to $16 \mathrm{~h}$ compared to that in the control group $(P<0.01$; Fig. 9A). StAR protein expression in the stress group also significantly decreased from 0 to $16 \mathrm{~h}$ compared to the control group $(P<0.01)$, similar to the trend shown by mRNA expression (Fig. 9B and C). These results indicated that restraint stress may inhibit the expression of Cyp11a1 and Star and also indicated that the in vivo decrease in progesterone levels following restraint stress were associated with down-regulation of Cyp11a1 and Star. Further, the protein CYP11A1 and StAR expression levels in the ovary at 0 and $24 \mathrm{~h}$ were explored in the metyrapone and vehicle groups. The expression of StAR was obviously higher in the metyrapone group than in the vehicle group at $0 \mathrm{~h}$ after restraint stress $(P<0.01$; Fig. 9D). There was no change in CYP11A1 expression between the

Figure 7 Effect of metyrapone on the endometrial breakdown and shedding during the stress period. Metyrapone (150 mg per kg) dissolved in sterile saline and vehicle were administered intraperitoneally (IP) $1 \mathrm{~h}$ prior to the restraint stress (at 15:30 on day 5.5). (A) Representative macroscopic and morphologic changes of the bilateral uterine horns at $24 \mathrm{~h}$ after treatment with metyrapone show that uterine horns treated with vehicle are dark red in color, whereas those treated with metyrapone are light pink. Morphological analysis showed that endometrial breakdown was inhibited by metyrapone. (a2) and (b2) represent higher magnifications of the areas indicated by the red square in (a1) and (b1). (B) At $0 \mathrm{~h}$, the serum level of corticosterone in metyrapone group was significant lower than vehicle group. (C) Serum levels of P4 (nmol/L) in the metyrapone group were significantly higher than those in the vehicle group after restraint stress. (D) At $0 \mathrm{~h}$, the serum levels of $\mathrm{FSH}$ in the metyrapone group were significantly higher than those in the vehicle group. In the vehicle group, serum levels of FSH were not changed before and after stress. (E) At $0 \mathrm{~h}$, there was a significant increase in serum concentrations of $\mathrm{LH}$ in the metyrapone group as compared to that in the vehicle group. Data are represented as mean \pm S.D. ${ }^{*} P<0.05,{ }^{* *} P<0.01$.

metyrapone and vehicle groups following restraint stress (Fig. 9D). The result showed that metyrapone, which inhibits corticosterone synthesis, may prevent progesterone from decreasing during restraint stress by inhibiting StAR expression, resulting in the inhibition of endometrial disintegration. 

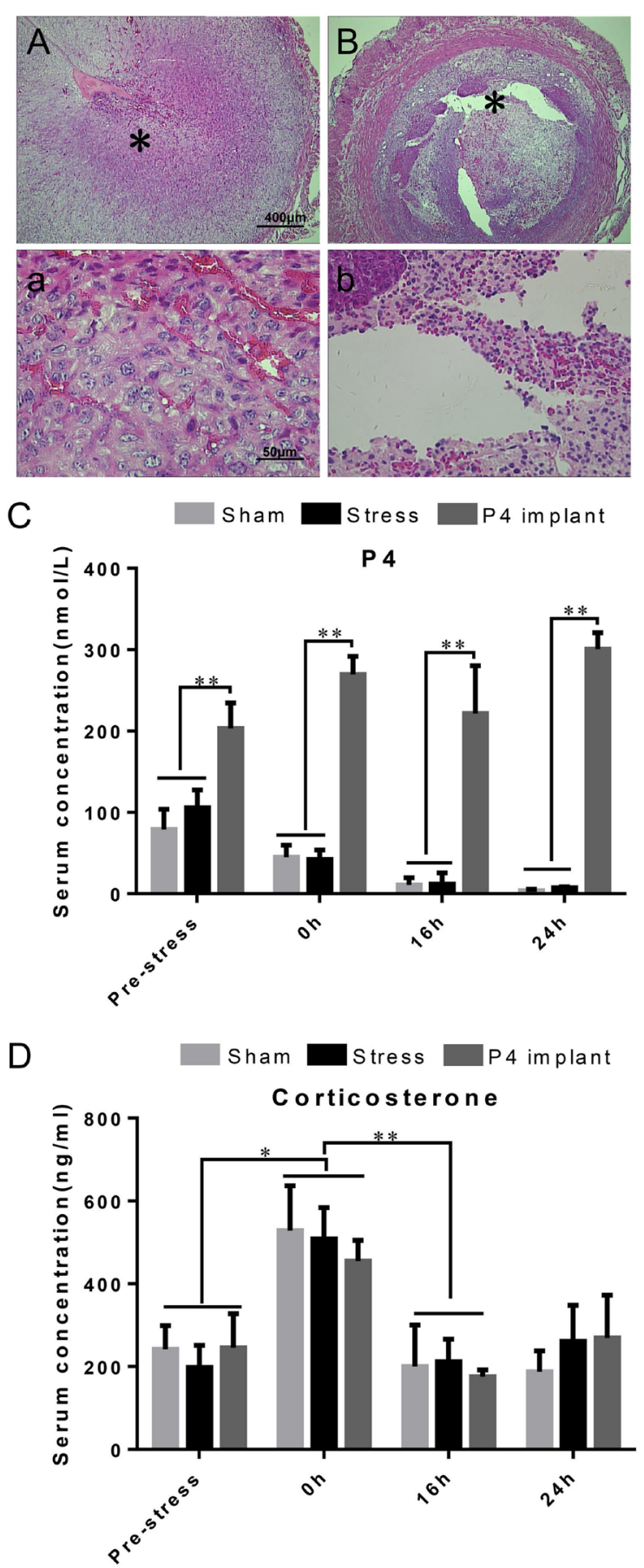

Figure 8 Effect of P4 implant on the endometrium breakdown and shedding during the stress period. (A) Cross-sections of uterine horns with P4 implant $24 \mathrm{~h}$ after restraint stress. (B) Cross-sections of stress uterine horns without P4 implant $24 \mathrm{~h}$ after restraint stress: (a) and (b) represent higher magnifications of the areas indicated by an asterisk in (A) and (B). (C) Serum concentrations of P4 $(\mathrm{nmol} / \mathrm{L})$ in the sham-operated group, P4 implant group and stress group before stress and at 0,16 and $24 \mathrm{~h}$ after restraint stress (the sham-operated group was not subjected to stress). (D) Serum corticosterone level in the sham-operated group, progesterone implant group, and stress group before stress and 0,16 and $24 \mathrm{~h}$ after restraint stress. Data were represented as mean \pm S.D. ${ }^{* *} P<0.01$.

\section{Discussion}

In this study, we utilized pseudopregnant mice with artificially induced decidualization to study the effect of acute stress on menstruation. To our knowledge, we are the first to discover that acute stress led to endometrial breakdown in menstruation due to P4 withdrawal. Further studies conducted by us revealed that P4 withdrawal induced by acute stress was associated with an increase in corticosterone and a decline in $\mathrm{LH}$ and $\mathrm{FSH}$ in the serum together and caused downregulation of StAR and CYP11A1 in the ovary.

In our study, the mice were put into $50 \mathrm{~mL}$ centrifuge tubes at $49 \mathrm{~h}$ following inducing decidualization. Successfully decidualized uteri uniformly enlarged at $49 \mathrm{~h}$ after oil injection. The 49-h duration for induction is optimal as reported previously in other studies (Brasted et al. 2003) as well as in our studies (Xu et al. 2007, Li et al. 2012, Wang et al. 2013, Chen et al. 2015). The time at which mice were removed from the tubes following restraint stress treatment was designated as $0 \mathrm{~h}$. Previous studies, as well as our studies observed that the endometrium underwent breakdown and shedding $24 \mathrm{~h}$ after stress treatment. Further, we found histomorphologic changes in the endometrium in $24 \mathrm{~h}$, wherein the endometrium showed focal death at $8 \mathrm{~h}$ in the mouse menstrual-like model. The zone of death was further expanded at $16 \mathrm{~h}$, which is the critical period of time for P4 withdrawal. At $24 \mathrm{~h}$, decidual stromal cells were completely dead and the entire decidual zone shed from the basal zone. Therefore, based on the above results, we selected these time points as times for testing following stress in this mouse menstrual model.

Matrix metalloproteinases have been identified as the major class of proteinases involved in the menstrual breakdown of endometrial tissues. The use of specific inhibitors of matrix metalloproteinases may block menstrual breakdown of the endometrium ( $\mathrm{Li}$ et al. 2012). In our study, we used MMPs, molecular markers of endometrial breakdown, to further analyze endometrial status. Immunohistochemical results indicated that MMP-2, MMP-9 and MMP-13expression increased in the decidual stromal cells at $16 \mathrm{~h}$. Previously, we demonstrated that the 12- to 16-h period following P4 withdrawal was the critical period for endometrial shedding and breakdown in the mouse menstrual-like model (Wang et al. 2013). This indicated that acute stress may promote the expression of MMP-2, MMP-9 and MMP-13, resulting finally in endometrial breakdown.

The results of the current study showed that corticosterone levels in the serum increased at $0 \mathrm{~h}$ following restraint stress, indicating that the HPA axis was activated by acute stress (Vazhayil et al. 2017). In the HPA axis, stress may promote the synthesis and release of $\mathrm{CRH}$ from the hypothalamus (Osterlund et al. 2014). CRH stimulates pituitary ACTH secretion (Almeida et al. 2004) and ACTH acts 

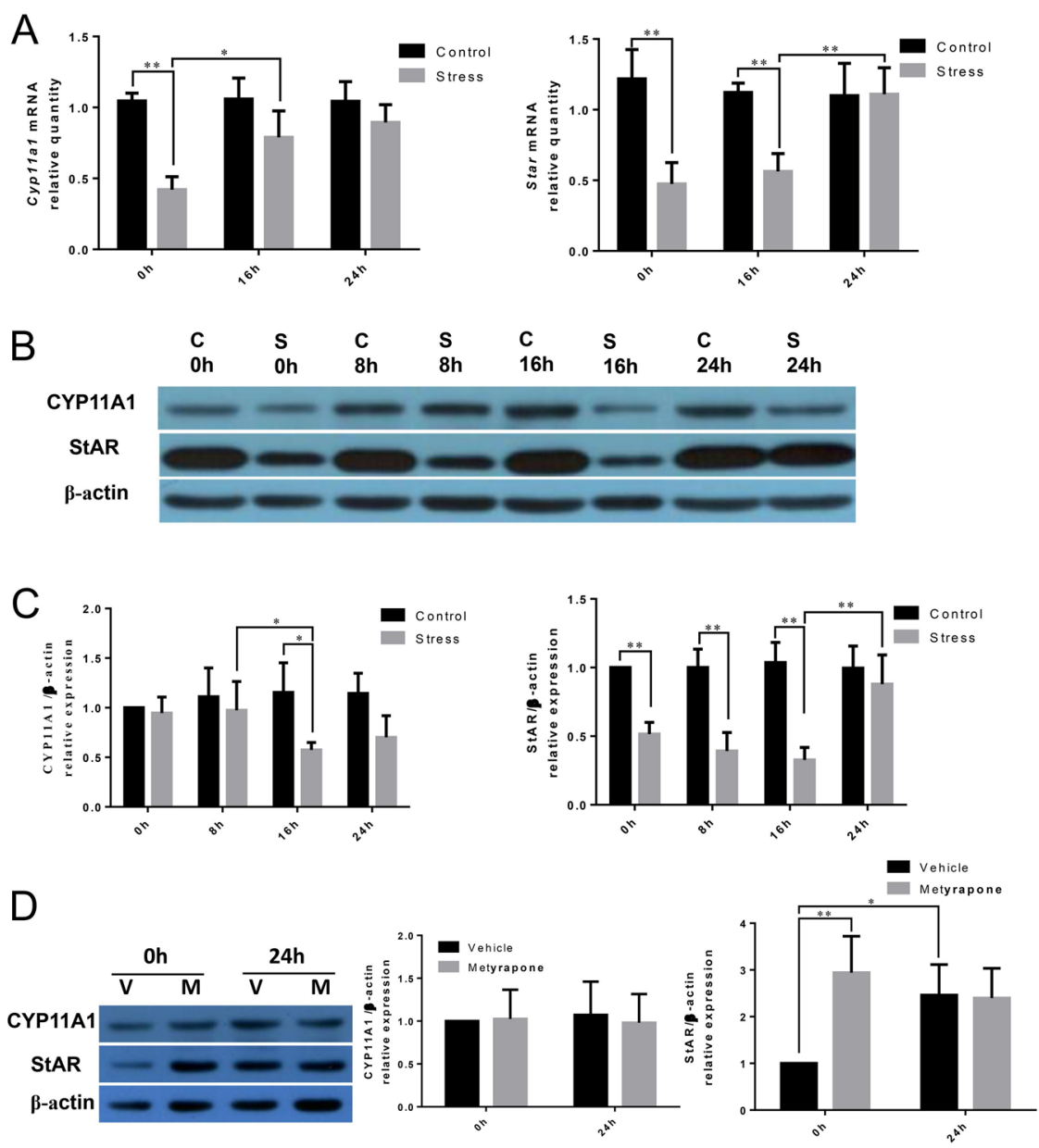

Figure 9 Expression patterns of Cyp11a1 and Star mRNA and protein after restraint stress. (A) Quantitative real-time PCR analysis demonstrates that the expression of Cyp 11a1 and Star mRNA levels decreased after restraint stress. (B and C) Western blot analysis shows that CYP11A1 protein levels decreased from 8 to $16 \mathrm{~h}$ after restraint stress. And StAR protein levels sharply decreased from 0 to $16 \mathrm{~h}$. (D) Western blot analysis of CYP11A1 and StAR in the ovary at 0 and $24 \mathrm{~h}$. $\beta$-actin was used as a loading control. C, control group; $M$, metyrapone group; $S$, stress group; $V$, vehicle group. Data are represented as mean \pm S.D. ${ }^{*} P<0.05,{ }^{* *} P<0.01$. on the adrenal glands to stimulate the biosynthesis and release of glucocorticoid hormones, which are major mediators of stress response. These studies suggested that restraint stress may stimulate the biosynthesis and secretion of glucocorticoids (Yates et al. 2017). Our results were consistent with those of previous studies and prove the efficacy of restraint stress efficiency in our study.

Corticosterone functions by binding to its intracellular receptor, the glucocorticoid receptor (GR), which is a transcription factor belonging to the nuclear receptor superfamily. In the absence of a ligand, GR resides predominantly in the cytoplasm. When bound to a ligand, GR travels to the nucleus from the cytoplasm. Therefore, a question arose as to whether corticosterone acts directly through the GR in the endometrium. Immunohistochemical staining showed that most GR-immunopositive signals were present in the cytoplasm of stromal cells following restraint stress, at levels which were not different compared to that of prestress. Moreover, western blot results showed that the GR expression following restraint stress was not significantly different compared to that of pre-stress. These results showed that stress may lead to endometrial breakdown and shedding due to an increase in corticosterone, but not due to an increase in the expression of GR receptor in the endometrium.

Glucocorticoids may inhibit ovarian estrogen/ progesterone secretion and pituitary luteinizing hormone (Tilbrook et al. 2000). Therefore, we evaluated the concentrations of $\mathrm{LH}$ and $\mathrm{FSH}$ in the serum. The results showed that the concentrations of $\mathrm{LH}$ and FSH were decreased at $0 \mathrm{~h}$ in the restraint stress group compared with those of the control group. Moreover, metyrapone, used to inhibit corticosterone synthesis during stress, may stimulate the secretion of $\mathrm{LH}$ and FSH compared to that of the vehicle group. We speculated that corticosterone may inhibit the secretion and synthesis of $\mathrm{LH}$ and FSH in the pituitary. These results may resolve issues related to hypothalamic amenorrhea of stress, which has been discussed in relation to chronic excessive exercise, malnutrition, eating disorders, anxiety and depression (Caronia et al. 2011, Bethea et al. 2013). Here, we hypothesized that restraint stress may activate the HPA axis, promoting the synthesis and release of corticosterone, which not only inhibits progesterone synthesis but also suppresses the secretion of $\mathrm{LH}$ and FSH in the pituitary, thereby blocking positive regulation of progesterone synthesis by LH (Mednick et al. 1980). This further clarifies the inhibitory effect of the HPG 
axis on the HPA axis. In order to further understand the regulation of menstruation, the mechanism underlying the interaction between the two axes needs to be further studied.

Interestingly, bleeding was observed in the vaginal orifice of mice and endometrial breakdown was also discovered at $24 \mathrm{~h}$ in the restraint stress group. Based on the above observations, we determined the levels of progesterone and estrogen in the serum. There was no significant change in serum estrogen concentrations between the two groups. However, the level of P4 decreased at $0 \mathrm{~h}$ after restraint stress, and there was a significant difference between the stress group and control group. The progesterone levels decreased and remained at a very low level until $24 \mathrm{~h}$ following stress, and there was a significant difference between the two groups. In order to validate the above observations, metyrapone was administered intraperitoneally (IP) $1 \mathrm{~h}$ prior to restraint stress, and the results showed that metyrapone may inhibit endometrial disintegration caused by restraint stress and also prevent progesterone reduction induced by restraint stress. Further, mice were implanted with progesterone before acute stress treatment. However, acute stress did not break the endometrium down in the P4 implant group. Moreover, progesterone withdrawal is a well-known trigger for the initiation of menstruation (Finn \& Pope 1984, Brasted et al. 2003, Xu et al. 2007). These results showed that stress increased corticosterone levels, leading to a decline in progesterone, finally resulting in endometrial breakdown and shedding.

Further, the levels of StAR and CYP11A1, two ratelimiting enzymes for progesterone synthesis, were explored (Men et al. 2017). We found Star mRNA and protein expression decreased significantly from 0 to $16 \mathrm{~h}$ following restraint stress. Cyp11a1 mRNA expression significantly decreased at $0 \mathrm{~h}$, and protein expression decreased from 8 to $16 \mathrm{~h}$. Similarly, Star mRNA and Cyp11a1 mRNA were downregulated in rat Leydig cells during the course of stress, and StAR protein was also downregulated (Lin et al. 2014). These results indicated that decrease in progesterone in the serum following restraint stress was associated with downregulation of CYP11A1 and StAR. Importantly, in our study, Star mRNA and protein were significantly decreased after acute stress, which indicated that StAR may play a key role in the reduction of progesterone.

CYP11A1 catalyzes the conversion of cholesterol to pregnenolone (Chien et al. 2017), and StAR transports cholesterol from the outer to the inner mitochondrial membrane (Manna et al. 2009, Zhang et al. 2015). From 0 to $16 \mathrm{~h}$, StAR protein decreased indicating that acute stress first inhibited the transport of cholesterol from the outer to the inner mitochondrial membrane. CYP11A1 protein decreased from 8 to $16 \mathrm{~h}$, indicating that acute stress may restrict the conversion of cholesterol to pregnenolone. But metyrapone may prevent the reduction of StAR expression induced by restraint stress, which is consistent with metyrapone preventing progesterone reduction due to restraint stress. This further showed that the decrease in progesterone, induced by restraint stress-corticosterone, was regulated by the decrease in StAR expression in the ovary.

The mechanism underlying stress-related inhibition of progesterone synthesis, and the final breakdown of the endometrium and its shedding, remains unclear. Our study indicates that stress may increase the level of glucocorticoids. Glucocorticoids such as corticosterone and cortisol can decrease the steady state level of Cyp11a1 mRNA (Hales \& Payne 1989). In cultured Leydig cells, glucocorticoids suppress the biosynthesis of the CYP11A1 and StAR (Whirledge \& Cidlowski 2013). Thus, it is interesting that downregulation of CYP11A1 and StAR may be associated with elevated corticosterone levels. Moreover, we observed that restraint stress inhibited concentrations of $\mathrm{LH}$ and $\mathrm{FSH}$ in the serum. In previous studies, CYP11A1 and StAR are rapidly induced in several hours after the ovulatory LH surge (Okada et al. 2016). In rat Leydig cells, the expression of Cyp 11a1 mRNA is regulated by LH (Lejeune et al. 1998). In cultured granulosa cells, CYP11A1 is induced by both $\mathrm{LH}$ and $\mathrm{FSH}$, according to the state of luteinization (Sekar et al. 2000, Okada et al. 2016). LH and FSH have been shown to stimulate Star mRNA expression in multiple species (Balasubramanian et al. 1997, Zhang et al. 2015). In rat granulosa cells, the expression of Star mRNA rapidly increased after hCG injection (Lee et al. 2013). In our results, the serum levels of LH and FSH were decreased by stress, and the expression patterns of CYP11A1 and StAR were downregulated, indicating that downregulation of CYP11A1 and StAR may be related to decreasing $\mathrm{LH}$ and FSH levels.

Our study indicated that stress may lead to endometrial breakdown and shedding. Interestingly, stress during pregnancy is associated with spontaneous preterm delivery (Shapiro et al. 2013, Yonkers et al. 2014, Hoffman et al. 2016). Case-control studies of women giving birth preterm and birth at term showed that there was a strong relationship between stress and spontaneous preterm delivery (Lilliecreutz et al. 2016). Moreover, in our previous studies of menstruation, molecules vital for menstruation are also associated with pregnancy (Xu et al. 2013, Chen et al. 2015). For example, COX-2, a rate-limiting enzyme that produces prostaglandin, increases in menstruation following P4 withdrawal in the mouse menstrual-like model. Interestingly, COX-2 is also strongly expressed in the stromal cells at the implantation site in early pregnancy of baboons. Another important molecule is HIF1A. HIF1A protein increases and is translocated into the nucleus during menstruation. A similar phenomenon was also found in mice during early pregnancy at day 5. Therefore, we contend that similar mechanisms may be involved in menstruation and pregnancy to a certain 
extent. The mechanism underlying menstruation may be a key cue to the process of pregnancy.

Menstruation is the periodic discharge of blood and mucosal tissue from the inner lining of the uterus through the vagina. However, menstrual disorders, which are common among females, may influence their quality of life (Williams \& Creighton 2012). Stress is one of several risk factors for irregular menstrual cycles (Bethea et al. 2013). Environmental stressors are thought to be associated with hypothalamic amenorrhea (Warren \& Fried 2001). Additionally, women with functional hypothalamic amenorrhea have higher serum cortisol concentrations compared to controls (Gordon et al. 2017). Previous clinical investigations have shown that stress can cause premenstrual syndrome, oligomenorrhea, amenorrhea and menorrhagia. Menorrhagia, but not amenorrhea, was the most common and prevalent menstrual disorder (Ekpenyong et al. 2011). In this study we found that stress can lead to endometrial disintegration and elevate corticosterone serum concentration of the mouse menstrual-like model.

In conclusion, the current study indicated that acute stress may activate the HPA axis and increase serum corticosterone levels, decrease LH and FSH levels and finally cause a decline in $\mathrm{P} 4$ levels leading to endometrial breakdown and shedding, which was blocked by $\mathrm{P} 4$ rescue. Further, corticosterone may reduce the $\mathrm{P} 4$ levels in vivo possibly by negative regulation of CYP11A1 and StAR. These findings may provide a theoretical basis for understanding menstruation and treating stressassociated menstrual disorders, especially menorrhagia.

\section{Declaration of interest}

The authors declare that there is no conflict of interest that could be perceived as prejudicing the impartiality of the research reported.

\section{Funding}

This work was supported by the National Nature Science Foundation of China (No. 81571410), (No. 81601254), CAMS Innovation Fund for Medical Sciences (No.2018-I2M-1-004) and the Beijing Nature Science Foundation (No. 7152115).

\section{References}

Allaway HC, Southmayd EA \& De Souza MJ 2016 The physiology of functional hypothalamic amenorrhea associated with energy deficiency in exercising women and in women with anorexia nervosa. Hormone Molecular Biology and Clinical Investigation 25 91-119. (https://doi. org/10.1515/hmbci-2015-0053)

Almeida OP, Waterreus A, Spry N, Flicker L \& Martins RN 2004 One year follow-up study of the association between chemical castration, sex hormones, beta-amyloid, memory and depression in men. Psychoneuroendocrinology 29 1071-1081. (https://doi.org/10.1016/j. psyneuen.2003.11.002)
Balasubramanian K, Lavoie HA, Garmey JC, Stocco DM \& Veldhuis JD 1997 Regulation of porcine granulosa cell steroidogenic acute regulatory protein (StAR) by insulin-like growth factor I: synergism with folliclestimulating hormone or protein kinase a agonist. Endocrinology 138 433-439. (https://doi.org/10.1210/endo.138.1.4894)

Bethea CL, Kim A \& Cameron JL 2013 Function and innervation of the locus ceruleus in a macaque model of Functional Hypothalamic Amenorrhea. Neurobiology of Disease 50 96-106. (https://doi. org/10.1016/j.nbd.2012.10.009)

Brasted M, White CA, Kennedy TG \& Salamonsen LA 2003 Mimicking the events of menstruation in the murine uterus. Biology of Reproduction 69 1273-1280. (https://doi.org/10.1095/biolreprod.103.016550)

Cao HZ, Xu XB, Chen XH, Wang JD \& He B 2010 Establishment of a menstruation model in pseudopregnant mouse. Journal of Reproductive Medicine 35-39. (https://doi.org/10.3969/j.issn.10043845.2010.01.008)

Caronia LM, Martin C, Welt CK, Sykiotis GP, Quinton R, Thambundit A, Avbelj M, Dhruvakumar S, Plummer L \& Hughes VA et al. 2011 A genetic basis for functional hypothalamic amenorrhea. New England Journal of Medicine 364 215-225. (https://doi.org/10.1056/NEJMoa0911064)

Chen X, Liu J, He B, Li Y, Liu S, Wu B, Wang S, Zhang S, Xu X \& Wang J 2015 Vascular endothelial growth factor (VEGF) regulation by hypoxia inducible factor-1 alpha (HIF1A) starts and peaks during endometrial breakdown, not repair, in a mouse menstrual-like model. Human Reproduction 30 2160-2170. (https://doi.org/10.1093/humrep/dev156)

Chen HJ, Spiers JG, Sernia C \& Lavidis NA 2016 Acute restraint stress induces specific changes in nitric oxide production and inflammatory markers in the rat hippocampus and striatum. Free Radical Biology and Medicine $\mathbf{9 0}$ 219-229. (https://doi.org/10.1016/j.freeradbiomed.2015.11.023)

Chien Y, Rosal K \& Chung BC 2017 Function of CYP11A1 in the mitochondria. Molecular and Cellular Endocrinology 441 55-61. (https:// doi.org/10.1016/j.mce.2016.10.030)

de Kloet ER, Joels M \& Holsboer F 2005 Stress and the brain: from adaptation to disease. Nature Reviews Neuroscience 6 463-475. (https:// doi.org/10.1038/nrn1683)

Ekpenyong CE, Davis KJ, Akpan UP \& Daniel NE 2011 Academic stress and menstrual disorders among female undergraduates in Uyo, South Eastern Nigeria - the need for health education. Nigerian Journal of Physiological Sciences 26 193-198.

Fenchel D, Levkovitz Y, Vainer E, Kaplan Z, Zohar J \& Cohen H 2015 Beyond the HPA-axis: the role of the gonadal steroid hormone receptors in modulating stress-related responses in an animal model of PTSD. European Neuropsychopharmacology $25 \quad 944-957 . \quad$ (https://doi. org/10.1016/j.euroneuro.2015.02.004)

Finn CA \& Pope M 1984 Vascular and cellular changes in the decidualized endometrium of the ovariectomized mouse following cessation of hormone treatment: a possible model for menstruation. Journal of Endocrinology 100 295-300. (https://doi.org/10.1677/joe.0.1000295)

Gitkind AI, Shah B \& Thomas M 2010 Epidural corticosteroid injections as a possible cause of menorrhagia: a case report. Pain Medicine 11 713-715. (https://doi.org/10.1111/j.1526-4637.2009.00775.x)

Gordon CM, Ackerman KE, Berga SL, Kaplan JR, Mastorakos G, Misra M, Murad MH, Santoro NF \& Warren MP 2017 Functional hypothalamic amenorrhea: an endocrine society clinical practice guideline. Journal of Clinical Endocrinology and Metabolism 102 1413-1439. (https://doi. org/10.1210/jc.2017-00131)

Hales DB \& Payne AH 1989 Glucocorticoid-mediated repression of P450scc mRNA and de novo synthesis in cultured Leydig cells. Endocrinology 124 2099-2104. (https://doi.org/10.1210/endo-124-5-2099)

Herzog AG \& Friedman MN 2001 Menstrual cycle interval and ovulation in women with localization-related epilepsy. Neurology 57 2133-2135. (https://doi.org/10.1212/WNL.57.11.2133)

Hoffman MC, Mazzoni SE, Wagner BD, Laudenslager ML \& Ross RG 2016 Measures of maternal stress and mood in relation to preterm birth. Obstetrics and Gynecology 127 545-552. (https://doi.org/10.1097/ AOG.0000000000001287)

Kjerulff KH, Erickson BA \& Langenberg PW 1996 Chronic gynecological conditions reported by US women: findings from the National Health Interview Survey, 1984 to 1992. American Journal of Public Health 86 195-199. (https://doi.org/10.2105/AJPH.86.2.195)

Lee L, Asada H, Kizuka F, Tamura I, Maekawa R, Taketani T, Sato S, Yamagata Y, Tamura H \& Sugino N 2013 Changes in histone 
modification and DNA methylation of the StAR and Cyp19a1 promoter regions in granulosa cells undergoing luteinization during ovulation in rats. Endocrinology 1 458-470. (https://doi.org/10.1210/en.2012-1610)

Lejeune H, Sanchez P, Chuzel F, Langlois D \& Saez JM 1998 Time-course effects of human recombinant luteinizing hormone on porcine Leydig cell specific differentiated functions. Molecular and Cellular Endocrinology 144 59-69. (https://doi.org/10.1016/S0303-7207(98)00153-1)

Li YF, Xu XB, Chen XH, Wei G, He B \& Wang JD 2012 The nuclear factorkappaB pathway is involved in matrix metalloproteinase-9 expression in RU486-induced endometrium breakdown in mice. Human Reproduction 27 2096-2106. (https://doi.org/10.1093/humrep/des110)

Lilliecreutz C, Laren J, Sydsjo G \& Josefsson A 2016 Effect of maternal stress during pregnancy on the risk for preterm birth. BMC Pregnancy Childbirth 16 5. (https://doi.org/10.1186/s12884-015-0775-x)

Lin H, Yuan KM, Zhou HY, Bu T, Su H, Liu S, Zhu Q, Wang Y, Hu Y \& Shan $Y$ et al. 2014 Time-course changes of steroidogenic gene expression and steroidogenesis of rat Leydig cells after acute immobilization stress. International Journal of Molecular Sciences 15 21028-21044. (https:// doi.org/10.3390/ijms151121028)

Liu G, Dong Y, Wang Z, Cao J \& Chen Y 2015 Restraint stress delays endometrial adaptive remodeling during mouse embryo implantation. Stress 18 699-709. (https://doi.org/10.3109/10253890.2015.1078305)

Manna PR, Dyson MT \& Stocco DM 2009 Regulation of the steroidogenic acute regulatory protein gene expression: present and future perspectives. Molecular Human Reproduction 15 321-333. (https:/doi.org/10.1093/ molehr/gap025)

Mednick DL, Barkley MS \& Geschwind II 1980 Regulation of progesterone secretion by $\mathrm{LH}$ and prolactin during the first half of pregnancy in the mouse. Journal of Reproduction and Fertility 60 201-207. (https://doi. org/10.1530/jrf.0.0600201)

Men Y, Fan Y, Shen Y, Lu L \& Kallen AN 2017 The steroidogenic acute regulatory protein (StAR) is regulated by the h19/let-7 axis. Endocrinology 158 402-409. (https://doi.org/10.1210/en.2016-1340)

Okada M, Lee L, Maekawa R, Sato S, Kajimura T, Shinagawa M, Tamura I, Taketani T, Asada H \& Tamura H et al. 2016 Epigenetic changes of the Cyp11a1 promoter region in granulosa cells undergoing luteinization during ovulation in female rats. Endocrinology 157 3344-3354. (https:// doi.org/10.1210/en.2016-1264)

O'Neill D 1958 Stress and disease: a review of principles. BMJ 2 285-287.

Osterlund CD, Thompson V, Hinds L \& Spencer RL 2014 Absence of glucocorticoids augments stress-induced Mkp1 mRNA expression within the hypothalamic-pituitary-adrenal axis. Journal of Endocrinology 220 1-11. (https://doi.org/10.1530/JOE-13-0365)

Rafique N \& Al-Sheikh MH 2018 Prevalence of menstrual problems and their association with psychological stress in young female students studying health sciences. Saudi Medical Journal 39 67-73. (https://doi. org/10.15537/smj.2018.1.21438)

Rudolph M, Docke WD, Muller A, Menning A, Rose L, Zollner TM \& Gashaw I 2012 Induction of overt menstruation in intact mice. PLoS ONE 7 e32922. (https://doi.org/10.1371/journal.pone.0032922)

Sekar N, Garmey JC \& Veldhuis JD 2000 Mechanisms underlying the steroidogenic synergy of insulin and luteinizing hormone in porcine granulosa cells: joint amplification of pivotal sterol-regulatory genes encoding the low-density lipoprotein (LDL) receptor, steroidogenic acute regulatory (stAR) protein and cytochrome P450 side-chain cleavage (P450scc) enzyme. Molecular and Cellular Endocrinology 159 25-35.

Shapiro GD, Fraser WD, Frasch MG \& Seguin JR 2013 Psychosocial stress in pregnancy and preterm birth: Associations and mechanisms. Journal of Perinatal Medicine 6 631-645. (https://doi.org/10.1515/jpm-20120295)

Tilbrook AJ, Turner Al \& Clarke IJ 2000 Effects of stress on reproduction in non-rodent mammals: the role of glucocorticoids and sex differences. Reviews of Reproduction 5 105-113. (https://doi.org/10.1530/ ror.0.0050105)
Tung LW, Lu GL, Lee YH, Yu L, Lee HJ, Leishman E, Bradshaw H, Hwang LL, Hung MS \& Mackie K et al. 2016 Orexins contribute to restraint stressinduced cocaine relapse by endocannabinoid-mediated disinhibition of dopaminergic neurons. Nature Communications 7 12199. (https://doi. org/10.1038/ncomms12199)

Vazhayil BK, Rajagopal SS, Thangavelu T, Swaminathan G \& Rajagounder E 2017 Neuroprotective effect of Clerodendrum serratum Linn. Leaves extract against acute restraint stress-induced depressive-like behavioral symptoms in adult mice. Indian Journal of Pharmacology 49 34-41. (https://doi.org/10.4103/0253-7613.201028)

Wang Q, Xu X, He B, Li Y, Chen X \& Wang J 2013 A critical period of progesterone withdrawal precedes endometrial breakdown and shedding in mouse menstrual-like model. Human Reproduction 28 1670-1678. (https://doi.org/10.1093/humrep/det052)

Warren MP \& Fried JL 2001 Hypothalamic amenorrhea. The effects of environmental stresses on the reproductive system: a central effect of the central nervous system. Endocrinology and Metabolism Clinics of North America 30 611-629. (https://doi.org/10.1016/S08898529(05)70204-8)

Whirledge S \& Cidlowski JA 2013 A role for glucocorticoids in stressimpaired reproduction: beyond the hypothalamus and pituitary. Endocrinology 154 4450-4468. (https://doi.org/10.1210/en.2013-1652)

Williams CE \& Creighton SM 2012 Menstrual disorders in adolescents: review of current practice. Hormone Research in Paediatrics $\mathbf{7 8}$ 135-143. (https://doi.org/10.1159/000342822)

Wu B, Chen X, He B, Liu S, Li Y, Wang Q, Gao H, Wang S, Liu J \& Zhang S et al. 2014 ROS are critical for endometrial breakdown via NF-kappaBCOX-2 signaling in a female mouse menstrual-like model. Endocrinology 155 3638-3648. (https://doi.org/10.1210/en.2014-1029)

Xiao E, Xia-Zhang L \& Ferin M 1999 Stress and the menstrual cycle: short- and long-term response to a five-day endotoxin challenge during the luteal phase in the rhesus monkey. Journal of Clinical Endocrinology and Metabolism 84 623-626. (https://doi.org/10.1210/ jcem.84.2.5448)

Xu XB, He B \& Wang JD 2007 Menstrual-like changes in mice are provoked through the pharmacologic withdrawal of progesterone using mifepristone following induction of decidualization. Human Reproduction 22 3184-3191. (https://doi.org/10.1093/humrep/dem312)

Xu X, Chen X, Li Y, Cao H, Shi C, Guan S, Zhang S, He B \& Wang J 2013 Cyclooxygenase-2 regulated by the nuclear factor-kappaB pathway plays an important role in endometrial breakdown in a female mouse menstrual-like model. Endocrinology 154 2900-2911. (https://doi. org/10.1210/en.2012-1993)

Yates N, Crew RC \& Wyrwoll CS 2017 Vitamin D deficiency and impaired placental function: potential regulation by glucocorticoids? Reproduction 153 R163-R171. (https://doi.org/10.1530/REP-16-0647)

Yonkers KA, Smith MV, Forray A, Epperson CN, Costello D, Lin H \& Belanger K 2014 Pregnant women with posttraumatic stress disorder and risk of preterm birth. JAMA Psychiatry 71 897-904. (https://doi. org/10.1001/jamapsychiatry.2014.558)

Zhang JY, Wu Y, Zhao S, Liu ZX, Zeng SM \& Zhang GX 2015 Lysosomes are involved in induction of steroidogenic acute regulatory protein (StAR) gene expression and progesterone synthesis through low-density lipoprotein in cultured bovine granulosa cells. Theriogenology $\mathbf{8 4}$ 811-817. (https://doi.org/10.1016/j.theriogenology.2015.05.016)

Received 28 March 2018

First decision 2 May 2018

Revised manuscript received 1 November 2018

Accepted 13 November 2018 